\title{
KOMBINASI METODE K-MEANS DAN DECISION TREE DENGAN PERBANDINGAN KRITERIA DAN SPLIT DATA
}

\author{
Elly Muningsih \\ Sistem Informasi, Universitas Bina Sarana Informatika \\ Jl. Kramat Raya No. 98 Kwitang, Senen, Jakarta Pusat \\ Email:elly.emh@bsi.ac.id
}

\begin{abstract}
Data mining is a process of looking for patterns or pulling large and selected data information using certain techniques or methods. The K-Means and Decision Tree methods are part of the Data Mining technique. This study will combine the K-Means method to cluster data into three clusters then the results of the clustering will be classified using the Decision Tree Method with a comparison of the Gain Ratio, Information Gain and Gini Index criteria. The data is processed into two, namely training data and testing data with a percentage of 70:30, 80:20 and 90:10. The results of the research are to find out which criteria produce the best decision tree and performance based on the highest accuracy value from each data group. The data is taken from the UCI Repository with a total of 811 records and 52 attributes. From the data processing carried out, it is known that for the 70:30 data split, the accuracy value with the Gain Ratio, Information Gain and Gini Index criteria gets the same value, namely 97.53. The Gain Ratio and Gini Index criteria produce the highest accuracy value, which is $98.15 \%$ for 80:20 split data. While Information Gain got the highest accuracy value of $98.77 \%$ for 90:10 data split.
\end{abstract}

Keyword : data mining, clustering, $k$-means, classification, decision tree

\begin{abstract}
Abstrak
Data mining merupakan suatu proses mencari pola atau menarik informasi data besar dan terpilih menggunakan teknik atau metode tertentu. Metode K-Means dan Decision Tree merupakan bagian dari teknik Data Mining. Penelitian ini akan mengkombinasikan metode $K$-Means untuk melakukan clustering data menjadi tiga cluster kemudian hasil dari clustering akan di klasifikasi menggunakan Metode Decision Tree dengan perbandingan kriteria Gain Ratio, Information Gain dan Gini Index. Data yang diolah di bagi (split) menjadi dua yaitu data training dan data testing dengan prosentase 70:30, 80:20 dan 90:10. Hasil dari penelitian untuk menemukan kriteria mana yang menghasilkan pohon keputusan dan performa terbaik berdasarkan nilai akurasi tertinggi dari masing-masing kelompok data. Data diambil dari Repository UCI dengan jumlah 811 record dan 52 atribut. Dari pengolahan data yang dilakukan diketahui untuk split data 70:30, nilai akurasi dengan kriteria Gain Ratio, Information Gain dan Gini Index mendapatkan nilai sama yaitu 97,53. Kriteria Gain Ratio dan Gini Index menghasilkan nilai akurasi tertinggi yaitu 98,15\% untuk split data 80:20. Sedangkan Information Gain mendapat nilai akurasi tertinggi 98,77\% untuk split data 90:10.
\end{abstract}

Kata kunci : data mining, clustering, $k$-means, klasifikasi, decision tree

\section{Pendahuluan}

Data mining adalah suatu proses untuk mengekstraksi informasi yang spesifik dari data kemudian disajikan dalam bentuk informasi yang relevan dan berguna agar dapat dimanfaatkan untuk menyelesaikan berbagai masalah [1]. Data mining juga dapat diartikan sebagai suatu proses mencari pola atau menarik informasi data besar dan terpilih menggunakan teknik atau metode tertentu agar ditemukan suatu pola yang sebelumnya tidak diketahui [2]. Menurut [3] dan [4] ada 6 (enam) teknik data mining yaitu Deskripsi, Estimasi, Prediksi, Klastering, Klasifikasi dan Asosiasi. Dalam penelitian ini teknik data mining yang digunakan adalah klastering (clustering) dan klasifikasi (Clasiffication).

Clustering merupakan suatu metode yang digunakan untuk membagi dataset menjadi beberapa kelompok yang memiliki kemiripan atau karakteristik yang sama [5]. Salah satu metode dalam clustering adalah metode $K$-Means. Metode $K$-Means merupakan salah satu dari metode pengelompokan data non-hierarki yang mempartisi data kedalam bentuk dua kelompok atau lebih dimana data yang berkarakteristik sama akan dimasukkan kedalam satu kelompok yang sama, sedangkan data yang memiliki karakteristik berbeda akan dikelompokan kedalam kelompok lainnya [6]. Metode $K$ Means disebutkan juga merupakan salah satu metode dalam fungsi clustering atau pengelompokan yang mengacu pada pengelompokkan data, observasi atau kasus berdasar kemiripan objek yang diteliti [7].

Klasifikasi sendiri merupakan suatu proses untuk menemukan model yang menjelaskan konsep atau kelas data yang bertujuan untuk memperkirakan kelas dari suatu objek yang label-nya tidak diketahui dimana model itu sendiri dapat berupa aturan "jika-maka", berupa pohon keputusan (decision tree), formula matematika atau neural network [8]. Proses klasifikasi didasarkan pada empat komponen [9] yaitu kelas (suatu variabel 
dependen kategorikal yang merepresentasikan "label" yang terdapat pada obyek), predictor (variabel independen yang direpresentasikan oleh karakteristik data), training dataset (merupakan satu set data yang berisi nilai dari kedua komponen di atas yang digunakan untuk menentukan kelas yang sesuai berdasarkan predictor) dan testing dataset (data baru yang akan diklasifikasikan oleh model yang telah dibuat dan akurasi klasifikasi dievaluasi)

Metode yang bisa digunakan dalam klasifikasi salah satunya adalah Decision Tree. Decision Tree baik digunakan untuk klasifikasi atau prediksi [10]. Decision Tree atau dikenal juga dengan pohon keputusan merupakan suatu teknik dalam data mining yang digunakan untuk mengeksplorasi data dengan cara membagi kumpulan data besar menjadi himpunan record yang lebih kecil dengan memperhatikan variabel tujuannya [11]. Decision Tree membangun tree (pohon) dimulai dari data pada simpul akar (root node) kemudian pilih sebuah atribut dan formulasikan sebuah logical test pada atribut tersebut, lakukan percabangan pada setiap hasil dari test, terus bergerak ke subset yang memenuhi simpul anak cabang (internal node) yang sesuai, lakukan proses rekursif dan ulangi hingga dahan-dahan dari tree memiliki contoh dari satu kelas tertentu [2].

Penelitian ini akan mengkombinasikan metode $K$ Means untuk melakukan pengelompokan data menjadi 3 cluster kemudian hasil dari clustering tersebut akan di klasifikasi menggunakan Metode Decision Tree dengan perbandingan kriteria Gain Ratio, Information Gain dan Gini Index. Data yang diolah sebelumnya akan di bagi (split) menjadi 2 yaitu data training dan data testing dengan perbandingan prosentase 70:30, 80:20 dan 90:10. Data diambil dari Repository UCI dengan jumlah 811 record dan 52 atribut. Pengolahan data dilakukan menggunakan aplikasi pengolah data RapidMiner. Hasil dari penelitian untuk menemukan kriteria mana yang menghasilkan pohon keputusan dan performa terbaik berdasarkan nilai akurasi tertinggi dari masing-masing kelompok data.

\section{Metode Penelitian}

Metode yang digunakan dalam penelitian ini adalah metode CRISP-DM (Cross Industry Standard Process for Data Mining). Metode CRISP-DM memiliki beberapa tahapan, yaitu mengumpulkan dataset, memilih atribut yang relevan, membangun model clustering dan model klasifikasi, menggunakan model clustering untuk pengelompokan data dan model klasifikasi perbandingan kriteria Gain Ratio, Information Gain dan Gini Index dan terakhir adalah evaluasi model [12].

\subsection{Dataset}

Dataset yang digunakan dalam penelitian ini adalah data transaksi yang diambil dari UCI Machine Learning (Repository UCI) dengan jumlah data awal 811 dan atribut 104. Data berisi informasi jumlah penjualan produk dalam kurun waktu 52 minggu, data minimal dan maksimal serta data nilai normal. Informasi data transaksi yang digunakan adalah Product_Code (P1, P2, P3,....P819) dimana ada data Product_Code yang hilang, data 52 minggu (W0, W1, ..., W51), data minimal penjualan $(M I N)$, data maksimal penjualan $(M A X)$ dan data nilai normalisasi mingguan (Normalised 0 , Normalised 1, ..., Normalised51).

\subsection{Preprocessing Data}

Dari dataset yang ada dilakukan pemilihan antribut yang akan digunakan yaitu Product_Code (P1, P2, P3 dan seterusnya) untuk spesial atribut sebanyak 811 dan atribut data mingguan (W0... W51) untuk regular atribut sebanyak 52 yang nantinya akan di proses dimana tipe data pada atribut yang digunakan adalah integer.

\subsection{Modelling dan Evaluasi}

Pada tahapan ini, dilakukan beberapa langkah untuk modelling menggunakan tools RapidMiner :

1. Modelling Metode Clustering K-Means Pada tahapan ini dilakukan clustering menggunakan metode $K$-Means dengan jumlah cluster sebanyak 3.

2. Modelling Metode Klasifikasi Decision Tree Pada modelling metode klasifikasi ini, langkahlangkah yang dilakukan adalah :

a. Data dibagi menjadi dua yaitu data training dan data testing dengan perbandingan 70 : $30,80: 20$ dan $90: 10$.

b. Untuk tiap-tiap pembagian data di buat modelnya dengan metode klasifikasi Decision Tree kemudian pada setting parameter criterion dipilih Gain Ratio, Information Gain atau Gini Index.

c. Tambahkan operator Cross Validation dan Performance untuk evaluasi dan mengetahui perbandingan tingkat akurasi masing-masing kriteria dengan pembagian data yang berbeda-beda.

d. Dari pengolahan yang dilakukan akan diketahui pembagian data training dan data testing terbaik juga pemilihan criterion terbaik yang menghasilkan akurasi tertinggi.

\section{Hasil dan Diskusi}

Pengolahan data dilakukan menggunakan komputer personal Intel Core i5, $8 G B R A M$, sistem operasi Windows 10 dan RapidMiner 9.5.001.

\subsection{Penerapan Metode K-Means}

Pengolahan data dengan metode clustering $K$ Means menggunakan jumlah cluster 3 menghasilkan anggota kelompok untuk masing-masing cluster yaitu cluster_0 sebanyak 490 anggota, cluster_1 sebanyak 124 anggota dan cluster_2 sebanyak 197 anggota ditampilkan pada Gambar 1. dibawah ini : 


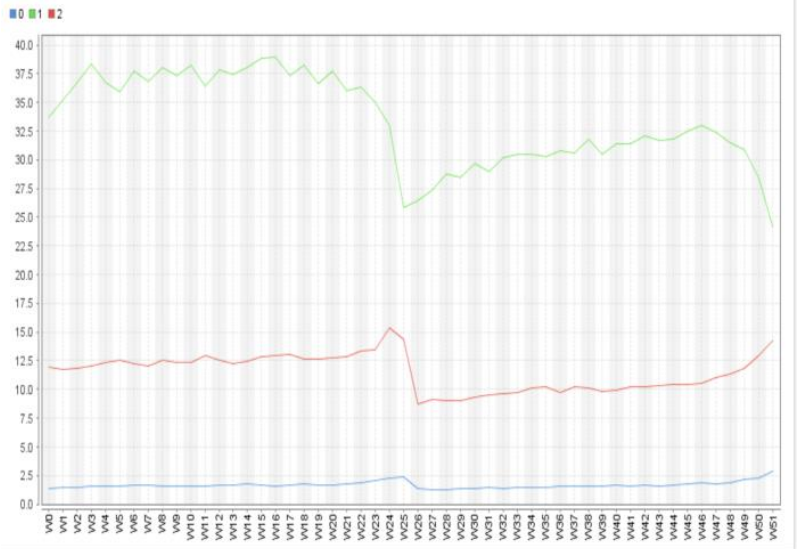

Gambar 1. Anggota tiap cluster

Dari gambar yang ditampilkan sebelumnya dapat dijelaskan bahwa anggota kelompok cluster_O adalah data mingguan dengan jumlah penjualan terkecil, cluster_1 adalah data mingguan dengan jumlah penjualan terbesar dan cluster_2 adalah data mingguan dengan jumlah penjualan sedang. Sedangkan representasi penyebaran anggota kelompok untuk data mingguan W0 ditampilkan pada Gambar 2. berikut ini :

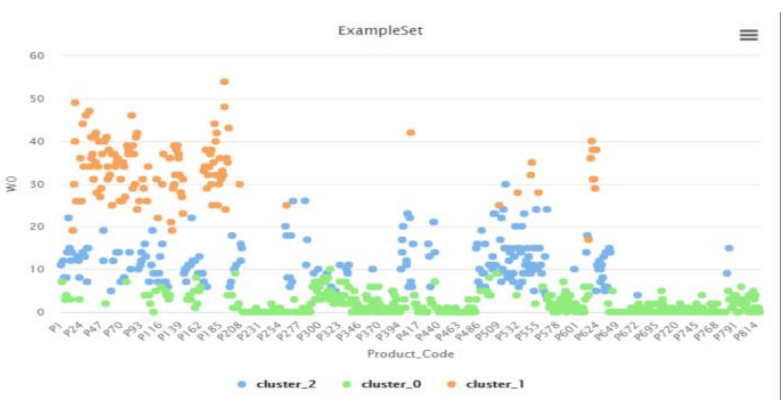

Gambar 2. Penyebaran anggota cluster

\subsection{Pohon Keputusan Metode Decision Tree}

\section{Perbandingan Kriteria Data Testing dengan Split Data 70:30}

Pada Gambar 3. dibawah ini ditampilkan pohon keputusan yang dihasilkan dari perbandingan kriteria Gain Ratio, Information Gain dan Gini Index dengan split data sebesar 70:30. Dari gambar dapat dijelaskan bahwa pada kriteria Gain Ratio, terlihat atribut W15 menjadi simpul akar dan hanya memiliki satu simpul cabang ke kiri yaitu atribut W0. Sedangkan kriteria Information Gain dan Gini Index memiliki hasil pohon keputusan yang sama dimana simpul akarnya adalah atribut W8 dan simpul akar ini memiliki dua cabang simpul ke kanan dan kiri. Cabang simpul kanan adalah atribut W15 dan simpul kiri adalah atribut W34.

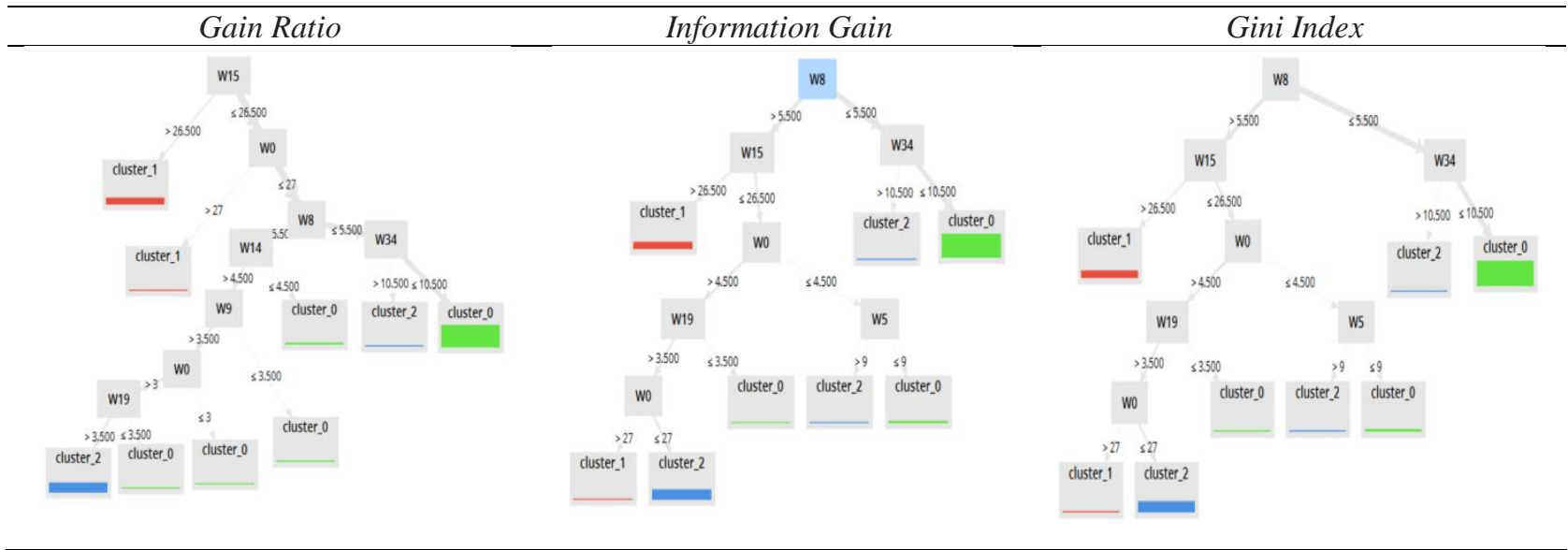

Gambar 3. Perbandingan Kriteria Data Testing dengan split data 70:30

\section{Perbandingan Kriteria Data Testing dengan Split Data 80:20}

Pada Gambar 4. dibawah ini ditampilkan pohon keputusan yang dihasilkan dari perbandingan kriteria Gain Ratio, Information Gain dan Gini Index dengan split data sebesar 80:20. Dari gambar dapat dijelaskan bahwa pada kriteria Gain Ratio, terlihat atribut W15 menjadi simpul akar dan hanya memiliki satu simpul cabang ke kiri yaitu atribut W3. Sedangkan kriteria
Information Gain dan Gini Index memiliki hasil pohon keputusan yang sedikit berbeda, dimana simpul akarnya sama yaitu atribut W8. Simpul akar kriteria Information Gain memiliki cabang simpul kanan adalah atribut W14 dan simpul kirinya adalah atribut W40. Sedangkan simpul akar kriteria Gini Index memiliki cabang simpul kanan adalah atribut W15 dan simpul kirinya adalah atribut W40. Cabang simpul kiri untuk kriteria Information Gain dan Gini Index adalah sama yaitu atribut W40. 


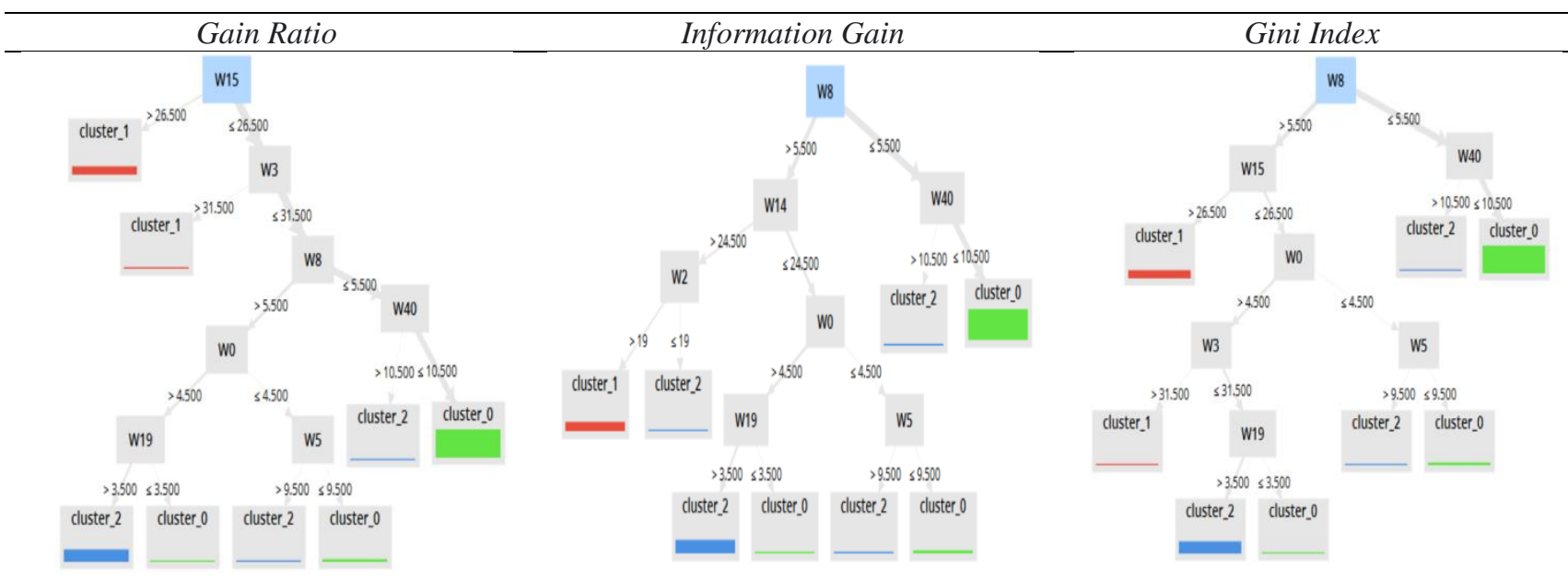

Gambar 4. Perbandingan Kriteria Data Testing dengan split data 80:20

\section{Perbandingan Kriteria Data Testing dengan Split Data 90:10}

Pada Gambar 5. dibawah ini ditampilkan pohon keputusan yang dihasilkan dari perbandingan kriteria Gain Ratio, Information Gain dan Gini Index dengan split data sebesar 90:10. Dari gambar dapat dijelaskan bahwa pada kriteria Gain Ratio, terlihat atribut W15 menjadi simpul akar dan hanya memiliki satu simpul cabang ke kiri yaitu atribut W3. Sedangkan kriteria
Information Gain dan Gini Index memiliki hasil pohon keputusan yang sedikit berbeda, dimana simpul akarnya sama yaitu atribut W8. Simpul akar kriteria Information Gain memiliki cabang simpul kanan adalah atribut W15 dan simpul kirinya adalah atribut W36. Sedangkan simpul akar kriteria Gini Index memiliki cabang simpul kanan adalah atribut W15 dan simpul kirinya adalah atribut W40. Cabang simpul kanan untuk kriteria Information Gain dan Gini Index adalah sama yaitu atribut W15.

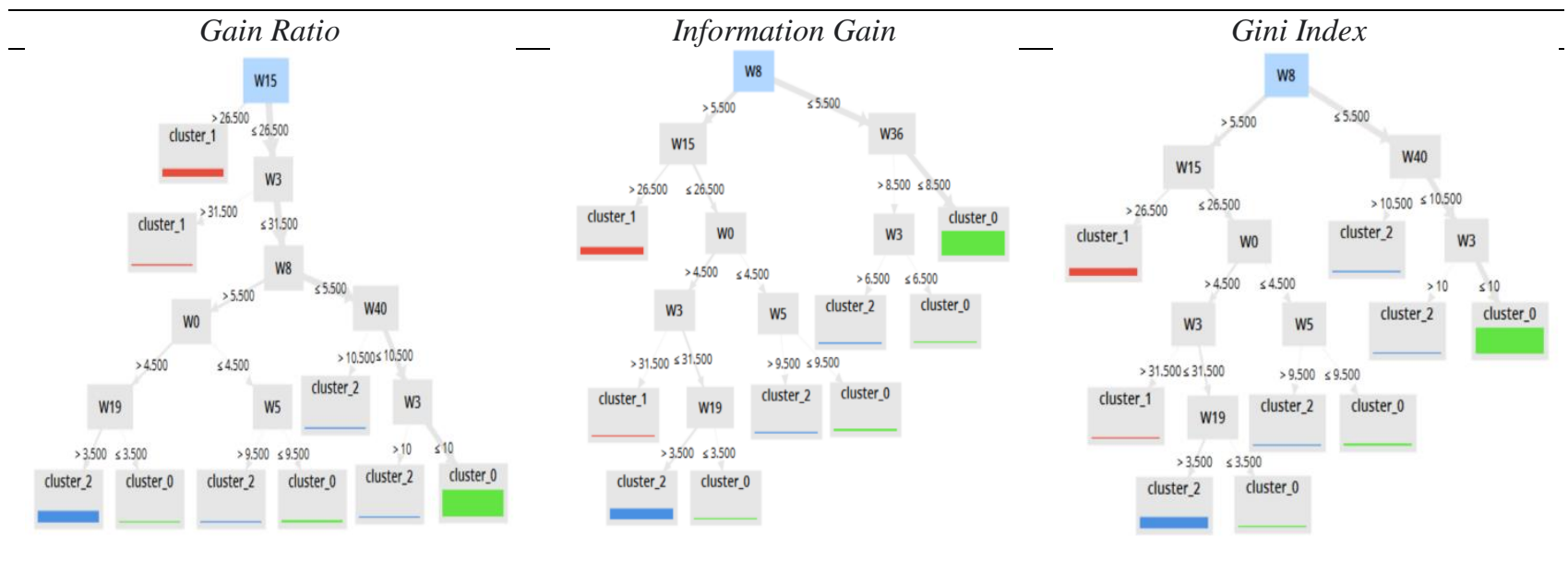

Gambar 4. Perbandingan Kriteria Data Testing dengan split data 90:10

\subsection{Nilai Akurasi}

Untuk mengukur akurasi digunakan Confusion Matrix. Berikut ini ditampilkan perhitungan berdasarkan data testing untuk kriteria Gain Ratio, Information Gain dan Gini Index.

\section{Perhitungan Berdasarkan Data Testing dengan Split} Data 70:30.

1. Pada kriteria Gain Ratio, untuk cluster_2 yang diprediksi dan benar ada 54, diprediksi cluster 0 ternyata cluster_2 ada 4, dan diprediksi cluster_1 ternyata cluster_2 ada 1 . Untuk cluster_O yang diprediksi dan benar ada 146, yang diprediksi cluster_2 ternyata cluster_0 ada 1 . Untuk cluster_1 yang di prediksi dan benar ada 37. Nilai akurasi pada kriteria Gain Ratio sebesar 97,53\%

2. Pada kriteria Information Gain dan Gini Index didapatkan hasil sama yaitu untuk cluster_2 yang diprediksi dan benar ada 55, diprediksi cluster 0 ternyata cluster_2 ada 3, dan diprediksi cluster_1 ternyata cluster_2 ada 1 . Untuk cluster_0 yang diprediksi dan benar ada 145, yang diprediksi cluster_2 ternyata cluster_0 ada 2 . Untuk cluster_1 yang di prediksi dan benar ada 37. Nilai akurasi pada kriteria Information Gain dan Gini Index sebesar $97,53 \%$ 


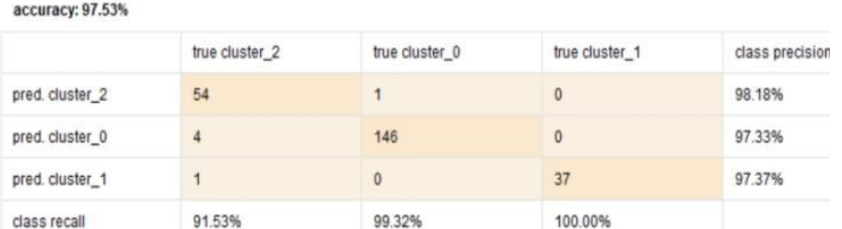

Gambar 5. Confusion Matrix Gain Ratio (70:30)

\begin{tabular}{|c|c|c|c|c|}
\hline & true cluster_22 & true cluster_0 & true cluster_1 & class precision \\
\hline pred. cluster_2 & 55 & 2 & 0 & $96.49 \%$ \\
\hline pred. cluster_0 & 3 & 145 & 0 & $97.97 \%$ \\
\hline pred cluster_1 & 1 & 0 & 37 & $97.37 \%$ \\
\hline class recall & $93.22 \%$ & $98.64 \%$ & $100.00 \%$ & \\
\hline
\end{tabular}

Gambar 6. Confusion Matrix Information Gain (70:30)

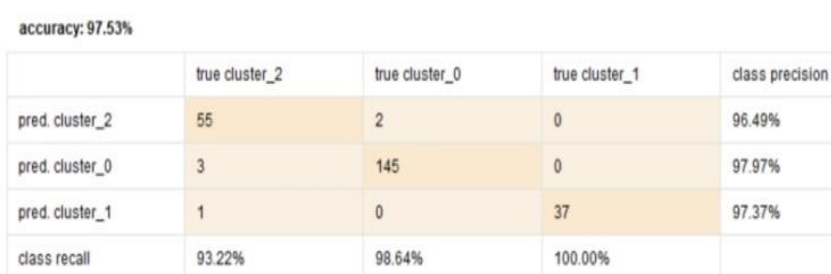

Gambar 7. Confusion Matrix Gini Index (70:30)

\section{Perhitungan Berdasarkan Data Testing dengan Split Data 80:20.}

1. Pada kriteria Gain Ratio dan Gini Index memiliki hasil yang sama yaitu cluster_2 yang diprediksi dan benar ada 37, diprediksi cluster_O ternyata cluster_2 ada 2. Untuk cluster_0 yang diprediksi dan benar ada 97, yang diprediksi cluster_2 ternyata cluster_O ada 1 . Untuk cluster_ 1 yang di prediksi dan benar ada 25. Nilai akurasi pada kriteria Gain Ratio sebesar 98,15\%

2. Pada kriteria Information Gain, untuk cluster_2 yang diprediksi dan benar ada 37, diprediksi cluster_O ternyata cluster_2 ada 2, dan diprediksi cluster_1 ternyata cluster_2 ada 1 . Untuk cluster_o yang diprediksi dan benar ada 97 , yang diprediksi cluster_2 ternyata cluster_0 ada 1 . Untuk cluster_1 yang di prediksi dan benar ada 23 dan diprediksi cluster_2 ternyata cluster_1 ada 2. Nilai akurasi pada kriteria Information Gain ini sebesar 96,91\%

\begin{tabular}{|l|l|l|l|l|}
\hline accuracy.98.15K & & & & \\
\hline pred cluste__2 & 37 & true cluster__ & true cluster_1 & class precision \\
\hline pred_cluster_0 & 2 & 1 & 0 & $97.37 \%$ \\
\hline pred_cluster_1 & 0 & 97 & 0 & $97.98 \%$ \\
\hline class recall & $94.87 \%$ & 0 & 25 & $100.00 \%$ \\
\hline
\end{tabular}

Gambar 8. Confusion Matrix Gain Ratio (80:20)

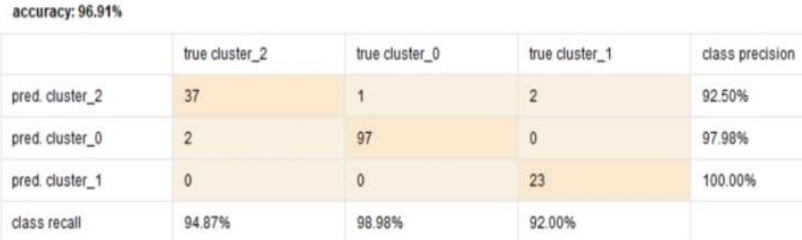

Gambar 9. Confusion Matrix Information Gain (80:20)

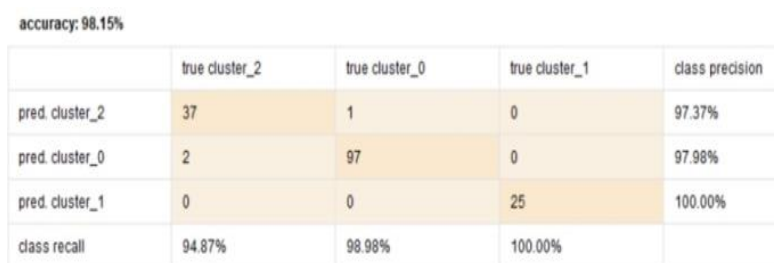

Gambar 10. Confusion Matrix Gini Index (80:20)

\section{Perhitungan Berdasarkan Data Testing dengan Split Data 90:10.}

1. Pada kriteria Gain Ratio dan Gini Index memiliki hasil sama yaitu cluster_2 yang diprediksi dan benar ada 19 dan diprediksi cluster_O ternyata cluster_2 ada 1. Untuk cluster_O yang diprediksi dan benar ada 48 dan yang diprediksi cluster_2 ternyata cluster_O ada 1 . Untuk cluster_ 1 yang di prediksi dan benar ada 12. Nilai akurasi pada kriteria Gain Ratio sebesar 97,53\%

2. Pada kriteria Information Gain, untuk cluster_2 yang diprediksi dan benar ada 20. Untuk cluster_0 yang diprediksi dan benar ada 48 dan diprediksi cluster_2 ternyata cluster_0 ada 1 . Untuk cluster_1 yang di prediksi dan benar ada 12. Nilai akurasi pada kriteria Information Gain ini sebesar 98,77\%.

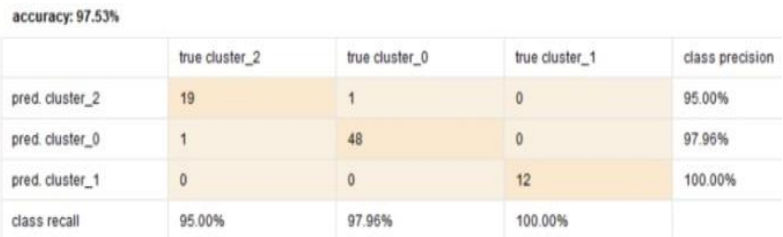

Gambar 11. Confusion Matrix Gain Ratio (90:10)

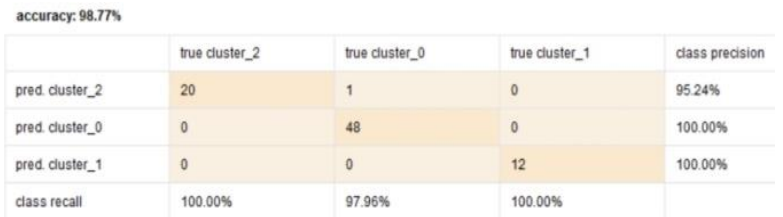

Gambar 12. Confusion Matrix Information Gain (90:10)

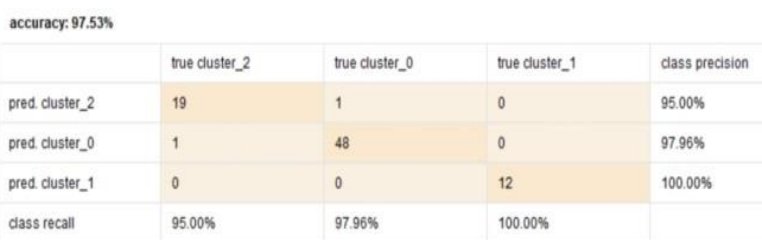

Gambar 13. Confusion Matrix Gini Index (90:10) 
Dari penjelasan sebelumnya dapat di kumpulkan jadi Tabel 1. dibawah ini yang menampilkan kriteria, split data dan nilai akurasinya. Jadi dapat dijelaskan bahwa jenis kriteria dan split data mempengaruhi nilai akurasi dari suatu pengolahan data yang memiliki tipe data integer.

Tabel 1. Perbandingan Nilai Akurasi

\begin{tabular}{lccc}
\hline \multirow{2}{*}{ Kriteria } & \multicolumn{3}{c}{ Nilai Akurasi (Split Data) } \\
\cline { 2 - 4 } & $70: 30$ & $80: 20$ & $90: 10$ \\
\hline Gain Ratio & 97,53 & $\mathbf{9 8 , 1 5}$ & 97,53 \\
Information Gain & 97,53 & 96,91 & $\mathbf{9 8 , 7 7}$ \\
Gini Index & 97,53 & $\mathbf{9 8 , 1 5}$ & 97,53 \\
\hline
\end{tabular}

Dari kriteria Information Gain dengan split data 90:10 didapatkan rule untuk data pada penelitian ini yaitu :

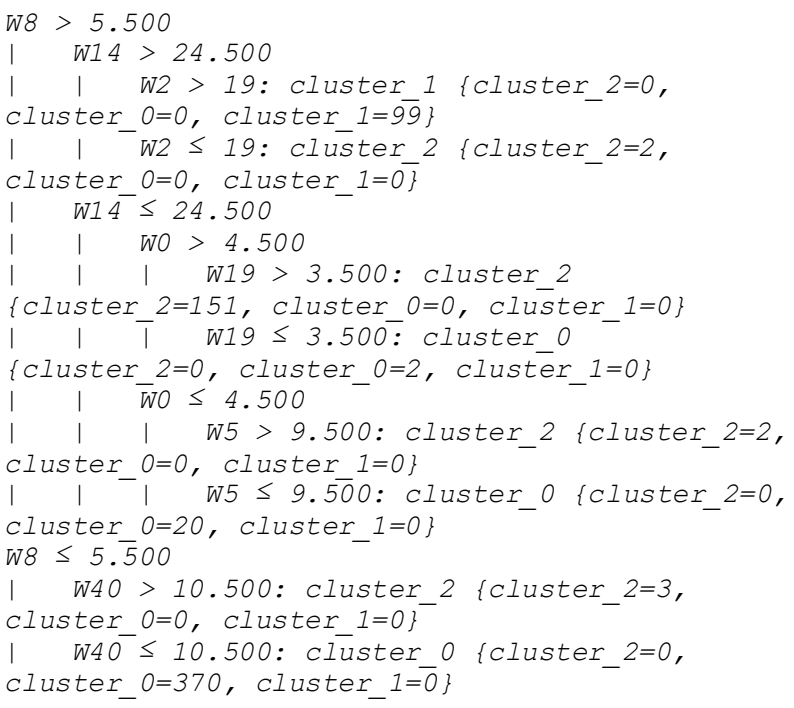

\section{Kesimpulan}

Dari pengolahan data yang sudah dilakukan yaitu mengkombinasikan metode clustering K-Means dan metode klasifikasi Decision Tree dengan membandingkan kriteria Gain Ratio, Information Gain, Gini Index dan pembagian (split) data 70:30, 80:20, 90:20 diketahui bahwa nilai akurasi tertinggi dihasilkan dari kriteria Information Gain dengan split data training dan testing sebesar 90:10 yaitu sebesar 98,77\%. Pada penelitian berikutnya bisa dilakukan pengolahan dengan menambahkan dan menguji beberapa data yang berbeda baik dari jenis atribut maupun tipe datanya.

\section{Daftar Pustaka}

[1] Wong, N. P., Damanik, F. N. S., Jaya, E. S., \& Rajaya, R. (2019). Perbandingan Algoritma C4 . 5 dan Classification and Regression Tree ( CART) Dalam Menyeleksi Calon Karyawan. 20(1), 11-18.

[2] Elmande, Y., \& Widodo, P. (2012). Pemilihan Criteria Splitting dalam Algoritma Iterative Dichotomiser 3 (ID3) untuk Penentuan Kualitas Beras: Studi Kasus Pada Perum Bulog Divre
Lampung. Jurnal TELEMATIKA MKOM, 4(1), 10 Retrieved from http://demo.pohonkeputusan.com/files/PEMILIH AN CRITERIA SPLITTING DALAM ALGORITMA ITERATIVE DICHOTOMISER 3 (ID3) UNTUK PENENTUAN KUALITAS BERAS.pdf

[3] Larose, D. T., \& Larose, C. D. (2014). Discovering Knowledge in Data: An Introduction to Data Mining: Second Edition. In Discovering Knowledge in Data: An Introduction to Data Mining: Second Edition (Vol. 9780470908). https://doi.org/10.1002/9781118874059

[4] Noviyanto, N. (2020). Penerapan Data Mining dalam Mengelompokkan Jumlah Kematian Penderita COVID-19 Berdasarkan Negara di Benua Asia. Paradigma - Jurnal Komputer Dan Informatika, 22(2), 183-188. https://doi.org/10.31294/p.v22i2.8808

[5] Muningsih, E., Nur, H. M., Dwi Imaniawan, F. F., Saifudin, Handayani, V. R., \& Endiarto, F. (2020) Comparative Analysis on Dimension Reduction Algorithm of Principal Component Analysis and Singular Value Decomposition for Clustering. Journal of Physics: Conference Series, 1641(1). https://doi.org/10.1088/1742-6596/1641/1/012101

[6] Gustientiedina, G., Adiya, M. H., \& Desnelita, Y. (2019). Penerapan Algoritma K-Means Untuk Clustering Data Obat-Obatan. Jurnal Nasional Teknologi Dan Sistem Informasi, 5(1), 17-24. https://doi.org/10.25077/teknosi.v5i1.2019.17-24

[7] Muningsih, E. (2015). Penerapan Metode Fuzzy C-Means dengan Model Fuzzy RFM (Studi Kasus: Clustering Pelanggan Potensial Online Shop). Semantik, 157-161.

[8] Wirdasari, D. (2013). ANALISA TEKNIK PENENTUAN ATRIBUT DALAM MEMBUAT POHON KEPUTUSAN PADA PENAMBANGAN DATA. Jurnal Ilmiah Saintikom Sains Dan Komputer, 12(2).

[9] Gorunescu, F. (2011). Data mining: Concepts, models and techniques. In Intelligent Systems Reference Library (Vol. 12). https://doi.org/10.1007/978-3-642-19721-5

[10] Rahayu, E. S., Satria, R., \& Supriyanto, C. (2015). Penerapan Metode Average Gain, Threshold Pruning dan Cost Complexity Pruning Untuk Split Atribut Pada Algoritma C4.5. Journal of Intelligent Systems, 1(2), 91-97.

[11] Zega, S. A. (2014). Penggunaan Pohon Keputusan untuk Klasifikasi Tingkat Kualitas Mahasiwa Berdasarkan Jalur Masuk Kuliah. Seminar Nasional Aplikasi Teknologi Informasi (SNATI) Yogyakarta, 7-13.

[12] Sastry, S. H., \& Babu, P. M. S. P. (2013). Implementation of CRISP Methodology for ERP Systems. 2(05), 203-217. Retrieved from http://arxiv.org/abs/1312.2065 